\section{Disassociating tree species associations in the eastern United States}

\author{
Brice B Hanberry
}

Ecologists have a long history of describing species associations including oakhickory, one of the predominant associations in the eastern United States. But historically, oak composition did not appear particularly related to hickory composition. I assessed the relevance of the oak-hickory association and other associations using older and recent (c. 1981 and 2007) USDA Forest Service surveys. For common hickory and oak species, I determined percent composition (i.e., percent of total stems $\geq 12.7 \mathrm{~cm}$ in diameter, relative density or abundance) in ecological subsections, changes in composition throughout ranges, and compared composition of oaks and hickories and other potential associations using correlation and ordination. Oaks were among the most abundant species while hickories were minor species. Hickory composition was stable while the trajectory of oak continued to decrease during the survey intervals from presettlement dominance. Rank-order correlation between oaks and hickories throughout their ranges was about the maximum as for other species ( 0.55 and 0.42 during the two survey periods) and in the Oak-Hickory forest region, correlation between oaks and hickories was 0.04 (older surveys) and 0.16 (recent surveys). Oaks were not associated with hickory in the "oakhickory" forests of Missouri during the mid-1800s, nor were oaks associated with hickory more recently beyond correlations that occur between other eastern forest species. Oak-hickory association in particular is not an informative term for either historical open oak ecosystems or current eastern broadleaf forests. Mixed mesophytic associations, perhaps not best termed as an association, are eastern broadleaf forests where many tree species dominate forested ecosystems in the absence of filtering disturbance. Associations, even if species share similar traits, generally are not strong, stable in time, or extensive in space; differences between species result in different and changing distributions in response to the environment, land use, disease, and other influential factors.

Keywords: Eastern Broadleaf Forests, Mixed Mesophytic, Oak-hickory, Southern Mixed Forests, Sugar Maple-beech

\section{Introduction}

Plant ecologists have spent well over a century defining plant associations along successional pathways (Pound \& Clements 1898, Schmelz \& Lindsey 1970). Clements (1936) influenced plant classifications in both the United States and Great Britain

$\square$ University of Missouri, 203 Natural

Resources Building, 65211 Columbia, MO (United States of America)

@ Brice B Hanberry

(hanberryb@missouri.edu)

Received: Oct 22, 2013 - Accepted: Feb 24, 2014

Citation: Hanberry BB, 2014. Disassociating tree species associations in the eastern United States. iForest 7: 248-254 [online 2014-03-13] URL: http: / /www.sisef.it/ iforest/contents/?id=ifor1159-007

Communicated by: Marco Borghetti rican chestnut (Castanea dentata), due to near extirpation of chestnut (e.g., Eyre 1980, Monk et al. 1989, Dyer 2006).

Oak and hickory species are one of the predominant associations throughout the eastern United States since at least 1898 (Pound \& Clements 1898, Hanson 1922, Eyre 1980, Monk et al. 1989, Dyer 2006, Tang \& Beckage 2010, Pan et al. 2011, Domke et al. 2012, Elderd et al. 2013). Originally, oakhickory associations may have specified Quercus rubra-Carya ovata forests present in Missouri and in other states near grassland ecosystems, but by 1914 oak-hickory associations had been generalized throughout eastern forests (Livingston 1903, Fuller 1914, Nichols 1914, Clements 1936). Sampson (1927) stated that before 1900 over 30 well-described associations including oakhickory existed for Ohio.

Oak and hickory species are more abundant in upland forest rather than floodplain forests and hydric soils; therefore, oak-hickory associations generally refer to species in upland, mesic to xeric sites (Sampson 1927, Schmelz \& Lindsey 1970). The most common species of oak in the central eastern and southeastern regions (hot continental and subtropical divisions - ECOMAP 1993, USDA Forest Service - Fig. 1) of the eastern United States are white oak (Quercus alba, $4.6 \%$ of total stems - B. Hanberry unpublished data from USDA Forest Service Forest Inventory and Analysis), chestnut oak (Q. prinus, 2.3\%), northern red oak $(Q$. rubra, $2.1 \%)$, black oak (Q. velutina, $2.0 \%)$, and post oak ( $Q$. stellata, $1.9 \%)$. The most common species of hickories are pignut hickory (Carya glabra, 1.3\%), mockernut hickory (C. tomentosa, 1.2\%), shagbark hickory (C. ovata, $0.8 \%)$, black hickory $(C$. texana, $0.5 \%)$, and bitternut hickory $(C$. cordiformis, $0.4 \%$ ). Because there are numerous species of oak and hickories, with unique species attributes, not only may oaks not be associated with hickories, but hickories may not be associated with other hickories and oaks may not be associated with other oaks. For example, bitternut hickory typically is located in floodplain and riparian forests (Burns \& Honkala 1990).

Indeed, "oak-hickory" forests were not dominated by oak-hickory during the early- to mid-1800s. Rather, these forest types were open oak savannas and woodlands (Hanberry et al. 2012b, Hanberry et al. 2014b). In the stronghold of Braun's Oak-Hickory forest region in the Missouri Ozarks landscape (Fig. 1), forest composition (i.e., percent of total stems, relative density or abundance) was $26 \%$ white oak, $23 \%$ post oak, $19 \%$ black oak, and $7 \%$ blackjack oak, or $75 \%$ oak from four species, with a total of $79 \%$ oak including all species of oak (Hanberry et al. 2012a). Furthermore, the Mis- 

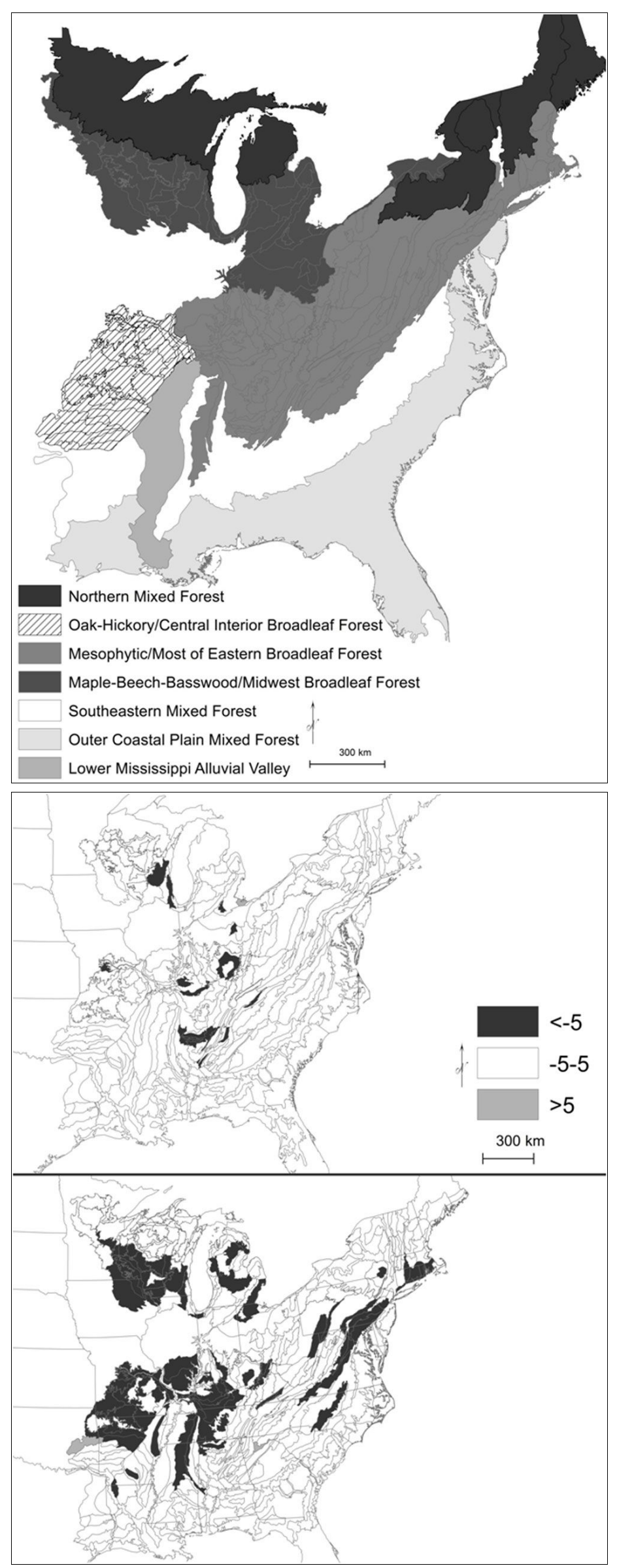

Fig. 1 - The Northern Mixed Forest (warm continental division shaded black), Eastern Broadleaf Forest (hot continental division shaded in darker gray colors and striped), and Southern Mixed Forest (subtropical division shaded in lighter gray colors and white) regions of the United States (ECOMAP 1993, USDA Forest Service). The Eastern Broadleaf Forest is divided into an "Oak-Hickory" forest region, a Maple-Beech-Basswood forest region, and a Mesophytic forest region, following Braun (1950). The Southern Mixed Forest is divided into three ecological provinces of Outer Coastal Plain Mixed Forest, Southeastern Mixed Forest, and Lower Mississippi Alluvial Valley.

Fig. 2 - Change in percent composition of hickory (upper panel) and oak (lower panel) ranges (five most common species combined). Outlined ecological subsections represent current range ( $\%$ composition $\geq 0.5$ ). 
souri Ozarks includes some riverine ecological subsections (Fig. 2 displays ecological subsections), where oak was 10 to $15 \%$ of composition, and conversely, in two subsections oaks were $95 \%$ of composition. In contrast, all combined hickory records were $5.5 \%$ of total composition. In four ecological subsections, hickory reached $8 \%$ to $10 \%$ of composition, and hickories were the most abundant after oaks where shortleaf pine was not present. However, the hickory genus in Missouri consists of the five common hickory species, and a few more species in addition, and thus each species probably contributed no more than 5\% of composition. Based on imbalanced composition, it seems more reasonable to label these forest types as oak or by dominant species of oak rather than as oak-hickory. Moreover, in the Missouri Ozarks, rank-order correlation between percent composition of the two genera was -0.09 and inclusion of all Missouri resulted in a correlation of -0.17 (B. Hanberry, unpublished data)

Given the lack of any particular balance or correlation between oak and hickory composition historically and differing dynamics and traits between the genera, I evaluated the validity of oak-hickory associations at large extents, including their ranges in the eastern US (Fig. 1), using the oldest USDA Forest Service Forest Inventory and Analysis (FIA) surveys and the most recently completed cycles. Associations should be composed of species that are dominant, whether by coverage, density, or biomass, and additionally, associated species should share similar traits, resulting in similar changes in composition in response to the environment. Do oaks and hickories have dominant composition and share compositional trajectories throughout oak and hickory ranges or in Braun's OakHickory forest region (Fig. 1)? If oaks were not associated by correlation with hickory in the "oak-hickory" forests of Missouri during the mid-1800s, were oaks associated by correlation or ordination with hickory more recently throughout oak and hickory ranges or in the Oak-Hickory forest region specified by Braun (1950)? Is there a strong association between any eastern forest species, for example oak-red maple (Acer rubrum) or oak-pine or sugar maple (Acer saccharum) -American beech (Fagus grandifolia) or red spruce (Picea rubens)-balsam fir (Abies balsamea)?

\section{Methods}

The USDA Forest Service Forest Inventory and Analysis (FIA DataMart, http://www.fia. fs.fed.us/tools-data) records data from long term forest plots located about every 20002500 ha across the country. Each plot contains four $7.3 \mathrm{~m}$ radius subplots, arranged as a central subplot surrounded by three outer subplots. Starting in 1999, plot designs and inventory cycles became standardized, with $20 \%$ of plots measured each year in the eastern US. Small trees $<12.7 \mathrm{~cm}$ in diameter are sampled in smaller areas within subplots and thus, I limited the study to trees $\geq 12.7 \mathrm{~cm}$ in diameter.

From the eastern US regions (warm continental, hot continental, and subtropical divi- sions - ECOMAP 1993; Fig. 1), I selected the most recently completed cycles, ranging from 2001 to $2012($ mean $=2007, \mathrm{SD}=2.2)$ and the oldest surveys, ranging from 1968 to $1995($ mean $=1981, S D=7.6)$. I retained ecological subsections that matched spatially between the oldest surveys and most recent cycles. Ecological subsections are the smallest ecological unit provided in FIA surveys (mean area $=700000$ ha, SD $=682000$ ECOMAP 1993; Fig. 2). I calculated percent composition (i.e., percent of total stems; adjusted for diameter bias present in variable radius plot sampling in older surveys) for all plots combined in each ecological subsection to determine dominance and changes in percent composition to assess trajectories for combined hickories and oaks, and other common species, by ecological regions and provinces, modified to better match Braun's forest regions. I mapped ranges $(\geq 0.5 \%$ of total species composition in ecological subsections to exclude transient presence or recent naturalization or plantings outside of ranges that may not become permanent) and changes in range, to examine trajectories in composition spatially. Because unidentified hickories in older surveys became identified in current surveys, I combined the most common five species of each genus and assigned all of the unknown hickory species to the five most common hickory species, which accounted for $95 \%$ of hickory stems. The five most common oak species accounted for $65 \%$ of oak stems.

I used Spearman rank-order correlation analysis (PROC CoRr, SAS software, version

Tab. 1 - Compositional percent (percent of total stems $\geq 12.7 \mathrm{~cm}$ in diameter) of common hickory and oak species and relevant species in older (approximately 1984 for each genus) and recent (approximately 2007) FIA surveys by ecological province (ECOMAP 1993) and forest region (Braun 1950).

\begin{tabular}{|c|c|c|c|c|}
\hline Province/Forest Region & Genus or species & $\begin{array}{c}\text { Older } \\
\text { (\%) }\end{array}$ & $\begin{array}{c}\text { Recent } \\
(\%)\end{array}$ & Change \\
\hline Midwest Broadleaf Forest/Sugar maple-bass- & hickory & 4.47 & 4.66 & 0.19 \\
\hline \multirow[t]{4}{*}{ wood-beech } & oak & 16.15 & 11.17 & -4.98 \\
\hline & American basswood & 3.99 & 4.24 & 0.25 \\
\hline & American beech & 0.65 & 0.58 & -0.07 \\
\hline & sugar maple & 4.36 & 5.26 & 0.90 \\
\hline Eastern, Appalachian, and eastern Central Interior & hickory & 8.32 & 7.34 & -0.98 \\
\hline \multirow[t]{8}{*}{ Broadleaf Forest/Mesophytic } & oak & 30.13 & 24.33 & -5.80 \\
\hline & American basswood & 0.52 & 0.59 & 0.07 \\
\hline & American beech & 1.63 & 1.83 & 0.20 \\
\hline & pines & 9.87 & 7.70 & -2.16 \\
\hline & red maple & 7.44 & 10.69 & 3.25 \\
\hline & sugar maple & 3.95 & 4.75 & 0.80 \\
\hline & tuliptree & 4.38 & 4.88 & 0.50 \\
\hline & yellow buckeye & 0.06 & 0.25 & 0.20 \\
\hline Western Central Interior Broadleaf Forest, Arkansas & hickory & 11.19 & 11.04 & -0.16 \\
\hline Ozarks and Ouachita and Valley/Oak-Hickory & oak & 47.45 & 39.78 & -7.67 \\
\hline \multirow[t]{2}{*}{ Southeastern Mixed Forest } & hickory & 4.54 & 3.66 & -0.88 \\
\hline & oak & 12.17 & 9.40 & -2.77 \\
\hline \multirow[t]{2}{*}{ Outer Coastal Plain Mixed Forest } & hickory & 1.24 & 0.71 & -0.53 \\
\hline & oak & 3.58 & 2.05 & -1.53 \\
\hline \multirow[t]{2}{*}{ Lower Mississippi Alluvial Valley } & hickory & 2.41 & 2.29 & -0.12 \\
\hline & oak & 3.99 & 2.82 & -1.18 \\
\hline
\end{tabular}


Tab. 2 - Significant correlations $\geq 0.4$ among oak (five most common species), hickory (five most common species), pine (excluding commerical pine species), and red maple. (n/a): not applicable.

\begin{tabular}{|c|c|c|c|c|c|c|c|c|c|}
\hline Survey & Species/genus & Oaks & Hickories & Pines & $\begin{array}{c}\text { Red } \\
\text { maple }\end{array}$ & $\begin{array}{c}\text { P-value } \\
\text { oaks }\end{array}$ & $\begin{array}{c}\text { P-value } \\
\text { hickories }\end{array}$ & $\begin{array}{l}\text { P-value } \\
\text { pines }\end{array}$ & $\begin{array}{c}\text { P-value } \\
\text { red maple }\end{array}$ \\
\hline Older & oaks & 1.00 & 0.55 & 0.20 & -0.08 & $\mathrm{n} / \mathrm{a}$ & $<0.01$ & $<0.01$ & 0.15 \\
\hline \multirow{10}{*}{ surveys } & butternut & 0.57 & 0.28 & -0.89 & -0.44 & 0.05 & 0.43 & 0.01 & 0.18 \\
\hline & hickories & 0.55 & 1.00 & -0.06 & -0.29 & $<0.01$ & $\mathrm{n} / \mathrm{a}$ & 0.37 & $<0.01$ \\
\hline & scarlet oak & 0.49 & 0.09 & 0.21 & 0.01 & $<0.01$ & 0.33 & 0.03 & 0.94 \\
\hline & sourwood & 0.48 & 0.02 & 0.12 & 0.48 & $<0.01$ & 0.93 & 0.52 & 0.01 \\
\hline & yellow-poplar & 0.47 & 0.30 & -0.07 & 0.25 & $<0.01$ & $<0.01$ & 0.40 & 0.00 \\
\hline & eastern redcedar & 0.00 & 0.39 & -0.24 & -0.07 & 0.99 & $<0.01$ & 0.02 & 0.52 \\
\hline & eastern hemlock & -0.05 & -0.53 & 0.25 & 0.50 & 0.64 & $<0.01$ & 0.01 & $<0.01$ \\
\hline & red maple & -0.08 & -0.29 & -0.31 & 1.00 & 0.15 & $<0.01$ & $<0.01$ & $\mathrm{n} / \mathrm{a}$ \\
\hline & black cherry & -0.09 & -0.16 & -0.25 & 0.44 & 0.18 & 0.04 & 0.00 & $<0.01$ \\
\hline & red mulberry & -0.36 & -0.30 & 0.24 & 0.51 & 0.09 & 0.17 & 0.44 & 0.03 \\
\hline Recent & oaks & 1.00 & 0.42 & 0.11 & -0.05 & $\mathrm{n} / \mathrm{a}$ & $<0.01$ & $<0.01$ & 0.51 \\
\hline \multirow[t]{2}{*}{ surveys } & butternut & 0.54 & -0.24 & -0.41 & -0.75 & $<0.01$ & $\mathrm{n} / \mathrm{a}$ & 0.42 & $<0.01$ \\
\hline & hickories & 0.42 & 1.00 & -0.06 & -0.24 & $<0.01$ & $<0.01$ & 0.02 & 0.01 \\
\hline
\end{tabular}

9.1, Cary, NC, USA) to statistically compare composition. I also correlated composition in the Oak-Hickory forest region (Fig. 1). I examined other correlations with oaks, including a combined pine genus (excluding commercial pines such as loblolly, Pinus taeda) and other common species, as well as correlations among sugar maple-American beech-eastern hemlock (Tsuga canadensis) and red spruce-balsam fir associations. I also used non-metric multidimensional scaling (NMS) ordination to represent species composition along axes based on the Sørensen/ Bray-Curtis distance measure ("ecodist" package in R - Goslee \& Urban 2007).

\section{Results}

In the Eastern Broadleaf Forest region, the five most common oak species combined were $27 \%$ of composition in older surveys and declined to $22 \%$ of composition in more recent surveys. Four of the five oak species contributed $4 \%$ to $7 \%$ of composition, and thus, oaks were among the most abundant species, in the following order of decreasing abundance: red maple, white oak, sugar maple, chestnut oak, yellow-poplar, northern red oak, and black oak. The five most common hickory species combined were $7 \%$ to $8 \%$ of composition during both survey intervals. Pignut hickory was the most common species at $2 \%$ of composition.

By ecological province/forest region, oak composition also declined while hickory composition remained relatively stable. Indeed, in Braun's Oak-Hickory forest region, oaks declined from $48 \%$ to $40 \%$ of composition, while hickories were about $11 \%$ of composition during both survey intervals (Tab. 1). Similarly, hickory composition throughout its range overall was stable relative to oak (Fig. 2).

Throughout the eastern US, rank-order correlation values in general were weak $(<0.4$ Tab. 2 and Tab. 3). After butternut (Juglans cinerea), hickories had the greatest correlations with oaks, of $r=0.55$ in older surveys and $r=0.42$ in more recent surveys. In the Oak-Hickory forest region, correlation between oaks and hickories was 0.04 (older surveys) to 0.16 (recent surveys) and not significant. Correlations between sugar maple and American beech were 0.52 in older surveys and 0.42 in recent surveys. Beech had

Tab. 3 - Significant correlations $\geq 0.4$ among sugar maple, American beech, red spruce, balsam fir, and eastern hemlock. (n/a): not applicable.

\begin{tabular}{|c|c|c|c|c|c|c|c|c|c|c|c|}
\hline Survey & Species/genus & $\begin{array}{l}\text { Sugar } \\
\text { maple }\end{array}$ & $\begin{array}{c}\text { American } \\
\text { beech }\end{array}$ & $\begin{array}{c}\text { Red } \\
\text { spruce }\end{array}$ & $\begin{array}{c}\text { Balsam } \\
\text { fir }\end{array}$ & $\begin{array}{l}\text { Eastern } \\
\text { emlock }\end{array}$ & $\begin{array}{l}\text { P-value } \\
\text { sugar } \\
\text { maple }\end{array}$ & $\begin{array}{c}\text { P-value } \\
\text { beech }\end{array}$ & $\begin{array}{l}\text { P-value } \\
\text { spruce }\end{array}$ & $\begin{array}{c}\text { P-value } \\
\text { fir }\end{array}$ & $\begin{array}{l}\text { P-value } \\
\text { hemlock }\end{array}$ \\
\hline \multirow{10}{*}{$\begin{array}{l}\text { Older } \\
\text { surveys }\end{array}$} & sugar maple & 1.00 & 0.52 & 0.01 & -0.06 & 0.09 & $\mathrm{n} / \mathrm{a}$ & $<0.01$ & 0.94 & 0.58 & 0.35 \\
\hline & American beech & 0.52 & 1.00 & 0.15 & 0.15 & 0.24 & $<0.01$ & $\mathrm{n} / \mathrm{a}$ & 0.34 & 0.28 & 0.02 \\
\hline & yellow birch & 0.43 & 0.58 & 0.30 & 0.16 & 0.13 & $<0.01$ & $<0.01$ & 0.05 & 0.17 & 0.19 \\
\hline & flowering dogwood & 0.40 & 0.11 & 0.00 & 0.00 & -0.83 & $<0.01$ & 0.40 & $<0.01$ & $<0.01$ & 0.01 \\
\hline & red maple & 0.20 & 0.39 & -0.43 & -0.31 & 0.50 & $<0.01$ & $<0.01$ & $<0.01$ & $<0.01$ & $<0.01$ \\
\hline & white ash & 0.13 & -0.02 & -0.60 & -0.40 & 0.45 & 0.08 & 0.79 & $<0.01$ & $<0.01$ & $<0.01$ \\
\hline & white spruce & 0.10 & -0.04 & 0.30 & 0.46 & -0.16 & 0.46 & 0.81 & 0.22 & $<0.01$ & 0.30 \\
\hline & red spruce & 0.01 & 0.15 & 1.00 & 0.76 & -0.47 & 0.94 & 0.34 & $\mathrm{n} / \mathrm{a}$ & $<0.01$ & $<0.01$ \\
\hline & balsam fir & -0.06 & 0.15 & 0.76 & 1.00 & -0.28 & 0.58 & 0.28 & $<0.01$ & $\mathrm{n} / \mathrm{a}$ & 0.02 \\
\hline & paper birch & -0.15 & 0.02 & 0.47 & 0.36 & -0.35 & 0.12 & 0.89 & $<0.01$ & $<0.01$ & $<0.01$ \\
\hline \multirow{8}{*}{$\begin{array}{l}\text { Recent } \\
\text { surveys }\end{array}$} & sugar maple & 1.00 & 0.42 & 0.10 & -0.05 & 0.11 & $\mathrm{n} / \mathrm{a}$ & $<0.01$ & 0.53 & 0.61 & 0.24 \\
\hline & American beech & 0.42 & 1.00 & 0.10 & 0.01 & 0.35 & $<0.01$ & $\mathrm{n} / \mathrm{a}$ & 0.51 & 0.97 & $<0.01$ \\
\hline & yellow birch & 0.41 & 0.55 & 0.42 & 0.34 & 0.21 & $<0.01$ & $<0.01$ & $<0.01$ & $<0.01$ & 0.04 \\
\hline & white ash & 0.32 & 0.05 & -0.59 & -0.45 & 0.45 & $<0.01$ & 0.51 & $<0.01$ & $<0.01$ & $<0.01$ \\
\hline & red spruce & 0.10 & 0.10 & 1.00 & 0.74 & -0.43 & 0.53 & 0.51 & $\mathrm{n} / \mathrm{a}$ & $<0.01$ & 0.01 \\
\hline & eastern redbud & 0.00 & 0.48 & 0.00 & 0.00 & 0.00 & 1.00 & 0.04 & $<0.01$ & $<0.01$ & $<0.01$ \\
\hline & balsam fir & -0.05 & 0.01 & 0.74 & 1.00 & -0.27 & 0.61 & 0.97 & $<0.01$ & $\mathrm{n} / \mathrm{a}$ & 0.03 \\
\hline & paper birch & -0.11 & 0.13 & 0.61 & 0.58 & -0.07 & 0.26 & 0.31 & $<0.01$ & $<0.01$ & 0.56 \\
\hline
\end{tabular}




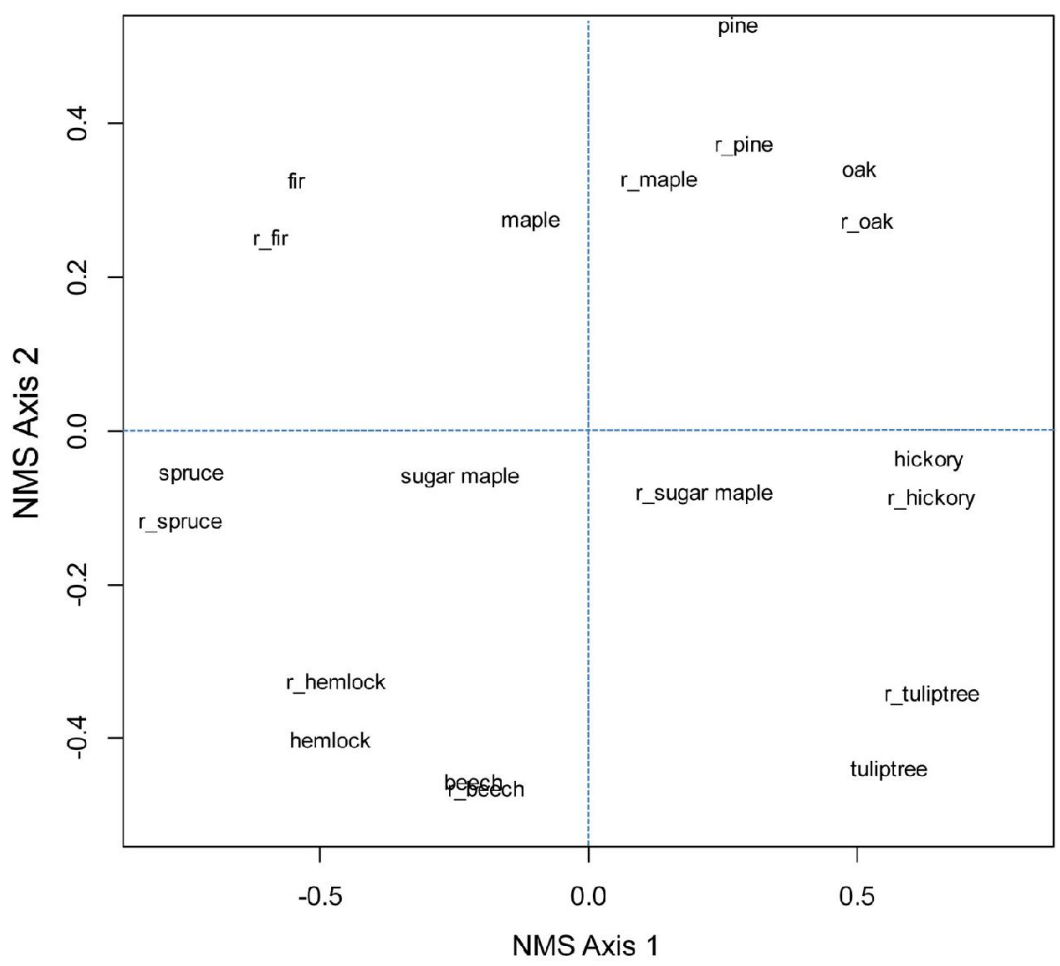

Fig. 3 - Ordination of five most common oak species (oak), five most common hickory species (hickory), (red) maple, pine species excluding loblolly and slash, sugar maple, (American) beech, (eastern) hemlock, (balsam) fir, (red) spruce, and (tuliptree) yellow-poplar for older and recent (prefix of $r_{-}$added) FIA surveys.

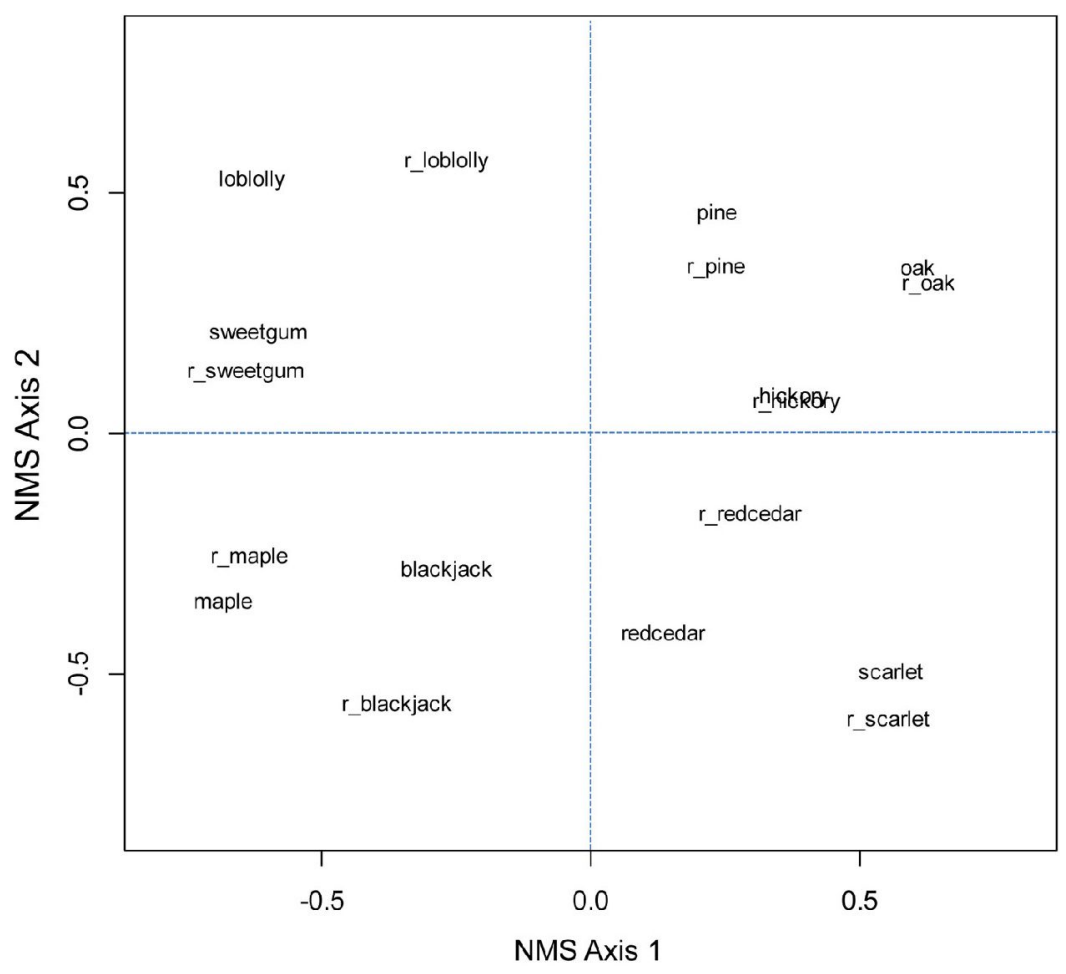

Fig. 4 - Ordination of five most common oak species (oak), five most common hickory species (hickory), (red) maple, pine species excluding loblolly and slash, loblolly pine, (eastern) redcedar, sweetgum, blackjack oak, and scarlet oak for older and recent (prefix of $r_{-}$added) FIA surveys in the Oak-Pine forest region. slightly stronger correlations with yellow birch and significant but weak correlations with eastern hemlock. Correlation between red spruce and balsam fir in both surveys was about 0.75 and significant. Ordinations, which account for similar values in composition, did not show that oak and hickory were more similar than oak and pine in either the eastern US or Oak-Hickory forest region (Fig. 3 and Fig. 4).

\section{Discussion}

Associations, even if significant, generally are not strong or stable. Associations are difficult to define consistently in space and time, particularly as spatial and temporal scales increase (Gleason 1926). Although correlation values between the most common oak and hickory species increased from historical forests of Missouri, which contributed the major extent of Braun's Oak-Hickory forest region, during the mid-1800s to current forests, $r$ values (i.e., 0.42 to 0.55 ) and ordinations did not show particular association between oaks and hickories. Ranges of the common oaks and hickories were similar, but otherwise oak composition was about three times as great as hickories and hickory composition was stable while the trajectory of oak continued to decrease from presettlement dominance.

When oak-hickory forest associations were described in the late $1800 \mathrm{~s}$, there may have been a greater compositional balance and spatial association of oak to hickory. Extensive harvest of interior eastern forests, which probably were open oak ecosystems where oaks dominated in the presence of frequent surface fires, occurred rapidly during approximately $1880-1920$ due to advances in industrialization (Hanberry et al. 2014a, but see Matlack 2013). Generally, harvest was somewhat selective based on economics to provide certain species and size classes to sawmills; dominant, large diameter oaks probably were the first tree removals. After forest harvest, effective fire suppression began about 1920. Although lack of disturbance initially favored dominant oak trees that were present and regenerating, ultimately, lack of fire allowed colonizing, firesensitive species to remain established (but see Matlack 2013). Forests increased in stem density, but oaks lost ground compared to numerous fire-sensitive species and are now $55 \%$ of the Missouri Ozarks (Hanberry et al. 2014a). Hickories were not particularly favored by fire and have increased in the Missouri Ozarks to $11 \%$ of composition.

Perhaps when oak declines to composition levels similar to hickory, correlation will increase, despite differences in life history traits. Nevertheless, it is not informative to name a forest ecosystem type based on two genera with composition no greater than numerous species or genera that are present. 
Rather, this type of association is termed "mixed mesophytic", or an association of numerous species ( $>20$ species of many genera - Braun 1935). Mixed mesophytic associations are diverse forests composed of varying species with no particular dominance or shared traits, aside from tolerance to current land use. Mixed mesophytic forests in the central eastern United States, where numerous broadleaf species are present, may be more typically named by location, composition, and vegetation state as eastern broadleaf forests, with "mixed" reserved for mixtures of broadleaf and needled species rather than a mixture of species (ECOMAP 1993 Fig. 1).

Mixed mesophytic forests currently are composed of species that historically were limited to sites protected from disturbance, which filtered species by traits. Historical disturbances otherwise created alternative states, for example, open oak or pine ecosystems in ecological provinces where there was frequent fire disturbance (but see Matlack 2013) or floodplain forests where there was flooding disturbance. Mesic sites are not as important for "mesophytic" species as disturbance-free areas, except in sites of extreme moisture stress in very xeric or hydric soils (Hanberry et al. 2012a). The stress of fire and flooding removes establishment of colonizing fire-sensitive and flooding-sensitive species. When species are released from disturbance stress because of fire suppression and river regulation, a wide range of disturbance-sensitive species establish and eventually dominate areas where there used to be an active disturbance regime. Currently, in areas where urbanization and forestry are major land uses, moderately shade-tolerant species such as red maple (see Tab. 1) are most abundant and in areas where intensive agriculture is the major land use, species that are tolerant to exposure are more abundant (Hanberry et al. 2014b).

Other widespread associations in the United States include sugar maple-American beech that developed over hundreds of years without disturbance. There appears to be evidence from historical records that sugar maple-beech was a more representative association than oak-hickory because both sugar maple and beech were dominant and longlived species with similar traits that represent forests after long periods without disturbance, perhaps a true "climax" association (Seischab 1990, Fuller et al. 1998, Bürgi et al. 2000, Lorimer 2001, Cogbill et al. 2002, Whitney \& DeCant 2003, Wang et al. 2010, Thomas-Van Gundy \& Strager 2012). Additionally, in the northern lower peninsula of Michigan, historical rank-order correlation was 0.87 (B. Hanberry, unpublished data). Nevertheless, the association was not consistent throughout the eastern US because the two species have different distributions.
American beech range extends south to Mexico and used to extend across the country, but now is more limited than sugar maple range, which extends further west. In the northeast, eastern hemlock may have had greater correlation with beech whereas sugar maple gained other tree associates such as American basswood in western regions outside of current beech distribution (Bürgi et al. 2000, Cogbill et al. 2002, Whitney \& Decant 2003). Because long periods without disturbance by current land use (i.e., tree removals occur more frequently than the lifespan of most tree species) are not present in the landscape, sugar maple and beech were not likely to continue as a dominant association; indeed, current correlation between the two species was not particularly strong and American beech currently is a minor species. Sugar maple has increased whereas beech has declined, probably due to multiple factors including forestry selection against beech and larger gaps that favors sugar maple, poor beech dispersal after harvest, and beech back disease (Cryptococcus fagisuga and Neonectria - Dyer 2001, Suffling et al. 2003). Likewise, the oak-chestnut association of the eastern side of eastern broadleaf forests has been disassociated by chestnut blight and subsequent preemptive harvest that removed potentially resistant genotypes. At smaller scales, red spruce-balsam fir may be one of the strongest associations $(r=0.75)$ due to shared traits, dominance in high elevation or latitude distributions, and similar trajectories.

\section{Conclusions}

We have inherited ecological terminology, some of which may never have been essential, including association-segregate, consociation, fasciation, lociation, formation, associes, associes-segregate, and developmental unit (Braun 1935). Oak-hickory association, which is still in use, is not descriptive of either historical open oak ecosystems or current eastern broadleaf forests. The mixed mesophytic association additionally may better align with current terminology by use of the term broadleaf or even deciduous forest rather than refer to an association composed of many species of no particular dominance or shared traits. Many disturbance-sensitive species are present in forested ecosystems in the absence of disturbance, but forest types of multiple species can be specified by location (i.e., eastern, southern, western, northern) and taxonomy (i.e., broadleaf or needled, angiosperm or gymnosperm, or deciduous or evergreen, and mixed to indicate balance between angiosperms and gymnosperms rather than a mixture of species - see Fig. 1). Forest implies a closed state, and in historical forest ecosystems, the open state may be incorporated with composition (i.e., open oak or pine forest ecosystems).
Although tree species share some overlapping traits and consequently, occupy similar sites, because of species-specific differences in traits and general lack of dominance by two species over a large shared extent, strong associations probably are limited in time and space. Additionally, because of differing species dynamics in response to driving factors such as land use and disease, associations do not persist and consequently, it is important not to model future forests based on transitory and weak current associations, i.e., project future movement by groups of species, when species will have different responses to environmental change. Even though more permanent than associations, forest ecosystem types also are not stable; without disturbance, open oak and pine ecosystems transitioned to closed forest composed of numerous species that are firesensitive. Mesophytic associations will endure indefinitely, but more simply termed eastern broadleaf forest in the eastern United States where angiosperms are dominant.

\section{Acknowledgments}

I thank anonymous reviewers who helped develop this manuscript.

\section{References}

Braun EL (1935). The undifferentiated deciduous forest climax and the association-segregate. Ecology 16:514-519. - doi: 10.2307/1930083

Braun EL (1950). Deciduous forests of eastern North America. Blakiston, Philadelphia, USA.

Burns RM, Honkala BH (1990). Silvics of North America: 2. Hardwoods. Agriculture Handbook 654, USDA Forest Service, Washington, DC, USA, pp. 877.

Bürgi M, Russell EWB, Motzkin G (2000). Effects of postsettlement human activities on forest composition in the north-eastern United States: a comparative approach. Journal of Biogeography 27:1123-1138. - doi: 10.1046/j.1365-2699.2000. 00484.x

Clements FE (1936). Nature and structure of the climax. Journal of Ecology 24: 252-284. - doi: $10.2307 / 2256278$

Cogbill CV, Burk J, Motzkin G (2002). The forests of presettlement New England, USA: spatial and compositional patterns based on town proprietor surveys. Journal of Biogeography 29 (10-11): 1279-1304. - doi: 10.1046/j.1365-2699. 2002.00757.x

Domke GM, Becker DR, D'Amato AW, Ek AR, Woodall CW (2012). Carbon emissions associated with the procurement and utilization of forest harvest residues for energy, northern Minnesota, USA. Biomass and Bioenergy 36: 141-150. doi: 10.1016/j.biombioe.2011.10.035

Dyer JM (2001). Using witness trees to assess forest change in southeastern Ohio. Canadian Journal of Forest Research 31: 1708-1718. - doi: 10.1139/x01-111

Dyer JM (2006). Revisiting the deciduous forests of eastern North America. BioScience 56: 341 - 
352. - doi: 10.1641/0006-3568(2006)56[341:RT DFOE $] 2.0 . \mathrm{CO} ; 2$

ECOMAP (1993). National hierarchical framework of ecological units. Ecoregions of the United States (map, revised edn), Scale 1:7500000 colored, unpublished administrative paper, USDA Forest Service, Washington, DC, USA, pp. 20.

Elderd BD, Rehill BJ, Haynes KJ, Dwyer G (2013). Induced plant defenses, host-pathogen interactions, and forest insect outbreaks. Proceedings of the National Academy of Sciences USA 110: 14978-14983. - doi: 10.1073/pnas.130075 9110

Eyre FH (1980). Forest cover types of the United States and Canada. Society of American Foresters, Washington, DC, USA, pp. 148. [online] URL: http://www.cabdirect.org/abstracts/198106 69723.html

Fuller GD (1914). Evaporation and soil moisture in relation to the succession of plant associations. Botanical Gazette 58: 193-234. - doi: 10 . 1086/331398

Fuller JL, Foster DR, Mclachlan JS, Drake N (1998). Impact of human activity on regional forest composition and dynamics in central New England. Ecosystems 1: 76-95. - doi: 10.1007 s100219900007

Gleason HA (1926). The individualistic concept of the plant association. Bulletin of the Torrey Botanical Club 53: 7-26. - doi: 10.2307/2479933 Goslee S, Urban D (2007). Ecodist: dissimilaritybased functions for ecological analysis. R package version 1.2.9, Reference manual. [online] URL: http://cran.r-project.org/web/packages/ecodist/ecodist.pdf

Hanberry BB, Dey DC, He HS (2012a). Regime shifts and weakened environmental gradients in open oak and pine ecosystems. PloS ONE 7: e41337. - doi: 10.1371/journal.pone.0041337 Hanberry BB, Palik BJ, He HS (2012b). Comparison of historical and current forest surveys for detection of homogenization and mesophication of Minnesota forests. Landscape Ecology 27: 1495-1512. - doi: 10.1007/s10980-012-9805-5

Hanberry BB, Kabrick JM, He HS (2014a). Densification and state transition across the Missouri Ozarks landscape. Ecosystems 17: 66-81. - doi: 10.1007/s10021-013-9707-7

Hanberry BB, Kabrick JM, He HS (2014b). Changing tree composition by life history strategy in a grassland-forest landscape. Ecosphere 5 (3). doi: 10.1890/ES13-00345.1

Hanson HC (1922). Prairie inclusions in the deciduous forest climax. American Journal of Botany 9: 330-337. - doi: 10.2307/2435570

Livingston BE (1903). The distribution of the upland plant societies of Kent County, Michigan. Botanical Gazette 35: 36-55. - doi: 10.1086/3283 15

Lorimer CG (2001). Historical and ecological roles of disturbance in eastern North American forests: 9.000 years of change. Wildlife Society Bulletin 29: 425-439.

Matlack GR (2013). Reassessment of the use of fire as a management tool in deciduous forests of eastern North America. Conservation Biology 27: 916-926. - doi: 10.1111/cobi.12121

Monk CD, Imm DW, Potter RL, Parker GG (1989). A classification of the deciduous forest of eastern North America. Vegetatio 80: 167181. - doi: 10.1007/BF00048040

Moss CE (1910). The fundamental units of vegetation: historical development of the concepts of the plant association and the plant formation. New Phytologist 9: 18-53. - doi: 10.1111/j.14698137.1910.tb05552.x

Nichols GE (1914). The vegetation of Connecticut III. Plant societies on uplands. Torreya 14: 167194.

Pan Y, Chen JM, Birdsey R, McCullough K, He L, Deng F (2011). Age structure and disturbance legacy of North American forests. Biogeosciences 8: 715-732. - doi: 10.5194/bg-8-715-2011

Pound R, Clements FE (1898). The vegetation regions of the prairie province. Botanical Gazette
25: 381-394. - doi: 10.1086/327698

Sampson HC (1927). The primary plant associations of Ohio: their distribution and their significance as habitat indices. Ohio Journal of Science 27: 301-310.

Schmelz DV, Lindsey AA (1970). Relationship among the forest types of Indiana. Ecology 51: 620-629. - doi: 10.2307/1934041

Seischab FK (1990). Presettlement forests of the Phelps and Gorham Purchase in western New York. Bulletin of the Torrey Botanical Club 117: 27-38. - doi: 10.2307/2997126

Suffling R, Evans M, Perera A (2003). Presettlement forest in southern Ontario: Ecosystems measured through a cultural prism. Forestry Chronicle 79: 485-501. - doi: 10.5558/tfc79485-

Tang G, Beckage B (2010). Projecting the distribution of forests in New England in response to climate change. Diversity and Distributions 16: 144-158. - doi: 10.1111/j.1472-4642.2009.006 $28 . x$

Thomas-Van Gundy MA, Strager MP (2012). European settlement-era vegetation of the Monongahela National Forest, West Virginia. Gen. Tech. Rep. NRS-101, USDA Forest Service, Newtown Square, PA, USA, pp. 43. [online] URL: http://www.fs.fed.us/nrs/pubs/gtr/gtr nrs101.pdf

Wang Y-C, Larsen CPS, Kronenfeld BJ (2010). Effects of clearance and fragmentation on forest compositional change and recovery after 200 years in western New York. Plant Ecology 208: 245-258. - doi: 10.1007/s11258-009-9702-4

Whitney GG, DeCant JP (2003). Physical and historical determinants of the pre- and post-settlement forests of northwestern Pennsylvania. Canadian Journal of Forest Research 33: 16831697. - doi: 10.1139/x03-079

Whittaker RH (1978). Approaches to classifying vegetation. In: "Classification of Plant Communities" (Whittaker RH ed). Dr W. Junk B. V. Publishers, The Hague, Boston, USA, pp. 1-32. 